\title{
Alzheimers sykdom og genetikk
}

BAKGRUNN Alzheimers sykdom er den hyppigste årsaken til demens. Nylig er det fremkommet viten om en rekke nye risikogener. Vi ønsker her å oppsummere kunnskap om genetiske forhold ved Alzheimers sykdom.

KUNNSKAPSGRUNNLAG Artikkelen er basert på søk i Alzgene, en database med oppsummeringer av genetiske assosiasjonsstudier ved Alzheimers sykdom, litteratursøk i PubMed og på forfatternes erfaring fra demensforskning.

RESULTATER En rekke mutasjoner i genene APP, PSEN1 og PSEN2 er beskrevet. Disse forårsaker om lag halvparten av alle tilfeller av den sjeldne og tidligdebuterende dominant arvelige formen for Alzheimers sykdom. Arvelighetsfaktoren, hvor mye av utviklingen av sykdommen hos et individ som er forklart av genetikk, er 60-80\% ved den vanlig forekommende sent debuterende Alzheimers sykdom. APOE \&4 er det sterkeste risikogenet for utvikling av denne sykdomsformen. Nylig er ytterligere ti gener som øker risikoen påvist ved helgenomassosiasjonsstudier. Genene koder for proteiner som er sentrale i kolesterolmetabolisme, immunaktivering og synaptiske cellemembranprosesser.

FORTOLKNING Nye hypoteser om sykdomsmekanismer for Alzheimers sykdom er foreslått på bakgrunn av funn av nye risikogener. Hypotesene dels erstatter og dels supplerer den tidligere dominerende amyloidhypotesen. De nye risikogenene peker mot potensial for nye biomarkører for spesifikke sykdomsprosesser og mot flere mulige nye angrepspunkter for fremtidig sykdomsmodifiserende behandling.

I Norge lever ca. 60000 personer med demens, og antallet forventes å dobles frem mot 2050 (1). Alzheimers sykdom er den hyppigste årsaken og utgjør i de fleste undersøkelsene om lag $65 \%$ av demenstilfellene (2). Sykdommen inndeles i tidlig og sent debuterende former, og skillet går ved 65 års alder (3). Den sent debuterende formen utgjør mer enn $95 \%$ av tilfellene (3). I tillegg skiller man i litteraturen mellom familiær, og sporadisk eller ikke-familiær Alzheimers sykdom. Den familiære typen beskrives vanligvis som dominant arvelig med høy penetrans og skyldes en rekke mutasjoner i ett av de tre enkeltgenene $A P P$, PSEN1 og PSEN2, men familiære former av sykdommen kan også defineres som sykdom hos minst to individer i samme familie der to av dem som er rammet av sykdommen er minst tredjegrads slektninger (3).

Ikke-familiære eller sporadiske former av sykdommen defineres som tilfeller med kun én person med diagnosen i en familie, eller flere tilfeller i samme familie som er adskilt av flere enn tre generasjoner eller slektsledd. Skal sykdommen defineres som sporadisk i en familie, kreves dokumentasjon på at familiemedlemmer ikke har fått Alzheimers sykdom selv om de har passert gjennomsnittlig debutalder for den sent debuterende formen (3).

I denne oversiktsartikkelen vil vi oppsummere tidligere forskning på området og deretter beskrive mer i detalj nye genetiske funn ved Alzheimers sykdom.

\section{Kunnskapsgrunnlag}

Oppsummering av tidligere forskning er basert på forfatternes egne kunnskaper om Alzheimers sykdom og genetikk samt et søk i PubMed i juni 2012 med søkeordene «Alzheimer's disease» og «genetics». Fra dette søket er det foretatt et skjønnsmessig utvalg av oversiktsartikler publisert etter 2008 og åtte eldre originalartikler. Nye studier av risikogener ble valgt ut på grunnlag av status i Alzgene-databasen per 1.6. 2012 (4). Søket ble oppdatert 15.3. 2013. Alzgene-databasen er en fritt tilgjengelig og oppdatert database (www.alzgene.org) over genetiske assosiasjonsstudier utført ved Alzheimers sykdom der gener med tilhørende referanser er rangert etter grad av kunnskapsgrunnlag. Kriterier for utvalget fra Alzgene-databasen var originalstudier med funn av risikogener som var signifikante på helgenomassosiasjonsstudienivå og replisert $\mathrm{i}$ et uavhengig utvalg. Søket ble foretatt av A.R. og utvalget av artikler ble foretatt av A.R. og C.G.

\section{Demens ved Alzheimers sykdom}

Klinisk karakteriseres sykdommen i tidlig stadium av hukommelsesforstyrrelser, desorientering og språkforstyrrelser som over tid går ut over evnen til selvstendig fungering (5). Det finnes påvirkbare risikofaktorer for å utvikle sykdommen, som lav utdanning, hypertensjon, overvekt, inaktivitet, røyking, diabetes, depresjon og hyperkolesterolemi $(6,7)$. Likevel mener mange i dag at hovedårsakene er høy alder og multifak-

\author{
Arvid Rongve \\ arvid.rongve@helse-fonna.no \\ Seksjon for alderspsykiatri \\ og \\ Seksjon for forskning \\ Klinikk for psykisk helsevern \\ Helse-Fonna \\ Haugesund \\ Dag Årsland
}

Regionalt senter for eldremedisin og samhandling (SESAM)

Stavanger universitetssjukehus

og

Alderspsykiatrisk avdeling

Akershus universitetssykehus

og

Alzheimer's Disease Research Center Karolinska Institutet

Caroline Graff

Alzheimer's Disease Research Center Karolinska Institutet

Se også kunnskapsprøve på www.tidsskriftet.no/quiz

\section{HOVEDBUDSKAP}

Arvelighetsfaktoren til vanlig sent debuterende Alzheimers sykdom er $60-80 \%$

Mutasjoner i de tre genene APP, PSEN1 og $P S E N 2$ forårsaker sjeldne $(<1 \%)$ familiære autosomalt dominante og tidligdebuterende former av sykdommen

$A P O E \& 4$ og ti nye risikogener forklarer nå inntil $50 \%$ av genetikken ved vanlig sent debuterende Alzheimers sykdom

Det er identifisert nye sykdomsmekanismer som involverer kolesterolmetabolismen i hjernen, nevroinflammasjon og synaptiske cellemembranprosesser 


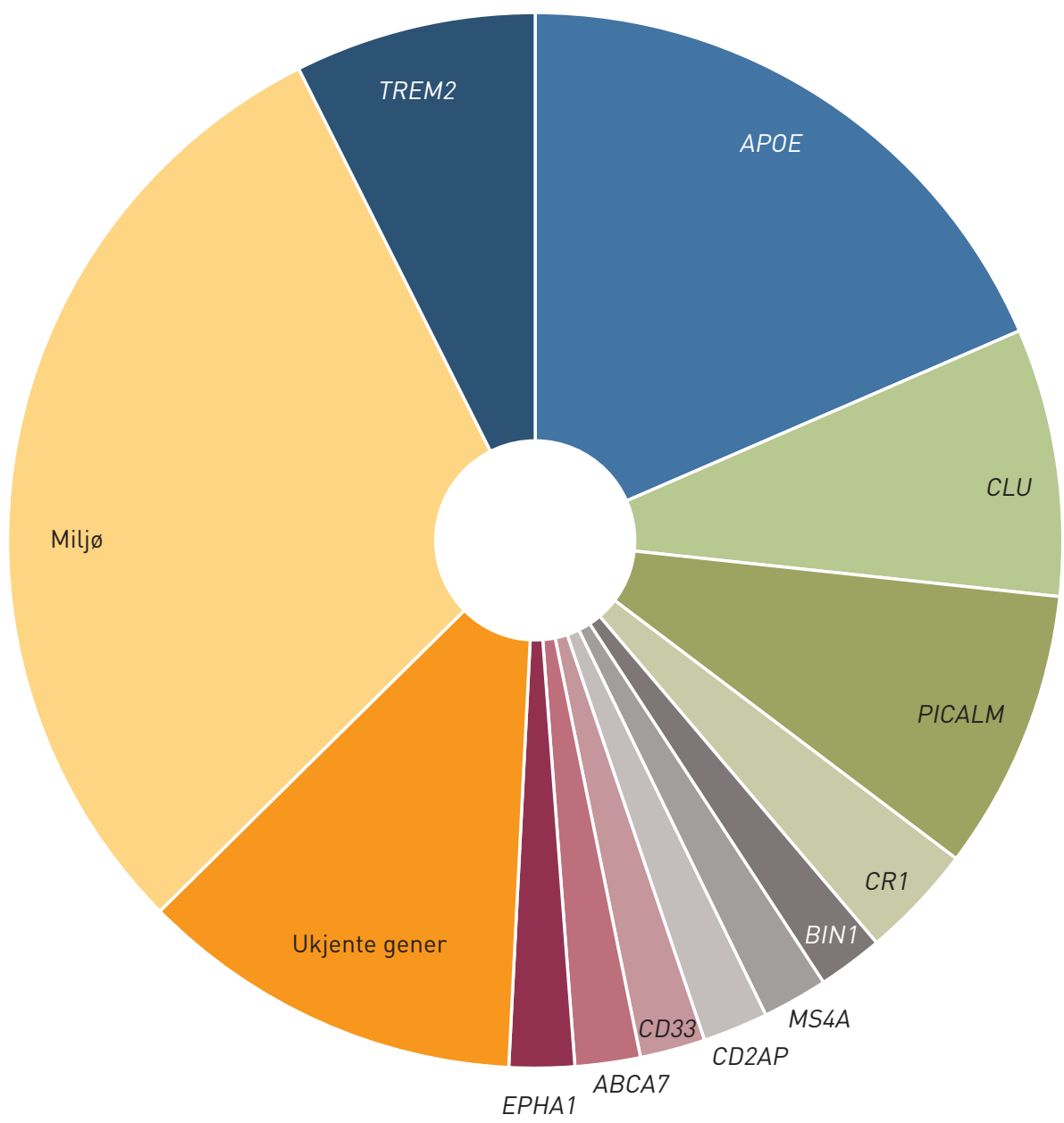

Figur 1 Miljø og ulike geners innvirkning på tilskrivbar relativ befolkningsrisiko for vanlig sent debuterende Alzheimers sykdom, dvs. hvor stor andel av sykdomstilfellene som kan forklares av de enkelte faktorene $(8,9,29,32-35)$

toriell arv. Flere kjente og en lang rekke ukjente gener, som hver for seg kun har en liten effekt på risikoen for å utvikle sykdommen, avgjør til sammen hvem som utvikler sykdommen og når denne debuterer. Basert blant annet på nordiske tvilling- og adopsjonsstudier vet vi nå at vanlig forekommende Alzheimers sykdom har en arvelighetsfaktor på $60-80 \%$, noe som betyr at utvikling av sykdommen hos et individ er $60-80 \%$ forklart av genetikk $(8,9)$.

Prevalensen av Alzheimers sykdom er om lag $1 \%$ ved 65 års alder. Deretter dobles den nesten hvert femte år, til om lag 30\% ved 90 års alder (10). Den totale kumulative insidensen før 96 års alder i befolkningen er på om lag $20 \%$, og denne dobles til rundt $40 \%$ om man har en førstegradsslektning med sykdommen $(11,12)$.

Nevropatologisk finnes opphopning av aggregert $\beta$-amyloid i form av plakk og hyperfosforylert tau-protein i form av nervefibriller i hjernen (5). Den nøyaktige funksjonen til det normale amyloid-proteinet er ikke fullstendig kartlagt, men det inngår i

sjon og nevronal plastisitet (13). Proteine tase dannes amyloid- $\beta$-peptider $(\mathrm{A} \beta)$ av ulik lige oligomerer, protofibriller og plakk (14). Ifølge amyloidhypotesen oppstår det en ubalanse med økt danning av disse formene med Downs syndrom ofte utvikler Alzheimers sykdom i tidlig alder (17).

\section{Dominante arvelige former}

1990-årene er beskrevet som det gylne tiåret for genetisk forskning på Alzheimers sykdom, fordi man i denne perioden påviste og kartla mutasjoner i tre ulike enkeltgener som til sammen er ansvarlige for om lag $50 \%$ av den sjeldne og dominant arvelige formen for Alzheimers sykdom med fullstendig penetrans (18). Sykdommen debuterer tidlig, ofte før 60 år, og en rekke ulike enkeltmutasjoner i de tre genene APP (19), PSEN1 (20) og PSEN2 (21) er beskrevet som årsak. APPgenet koder for amyloid forløperprotein og finnes på kromosom 21.

Nordiske forskere har nylig vist at en mutasjon (A673T) i APP-genet er assosiert med lavere forekomst av kognitiv svikt og lavere risiko for å utvikle Alzheimers sykdom (22). PSEN1 og PSEN2 koder for en familie av proteiner som tilhører gruppen preseniliner. Disse utgjør en del av $\gamma$-sekretaseenzymet, og ulike mutasjoner her fører til økt produksjon av uløselige former av amyloid- $\beta$-peptider som $A \beta-42$. Mutasjoner $i$ disse tre genene har derfor styrket amyloidhypotesen som en sentral forklaringsmodell ved Alzheimers sykdom, og det er på denne bakgrunn funnet nye potensielle angrepspunkter for sykdomsmodifiserende behandling, som $\gamma$-sekretasehemmere (23). Mutasjoner i disse tre genene forårsaker imidlertid mindre enn $1 \%$ av all Alzheimers sykdom (24). Så langt har man kartlagt at $18-50 \%$ av disse har en enkeltmutasjon i PSEN1 som årsak til dominant arvelig Alzheimers sykdom, 10-15\% skyldes mutasjon i $A P P$, og sjeldne familiære tilfeller skyldes mutasjon i PSEN2 (25). blir spaltet av $\alpha-, \beta-$ og $\gamma$-sekretaser. Ved spalting av $\beta$-sekretase etterfulgt av $\gamma$-sekrelengde, der de lengre formene som $A \beta 42$ har en økt tilbøyelighet til å aggregere til uløsesom dermed aggregerer og danner amyloide plakk som skader hjernecellene i utsatte områder og gir de kliniske symptomene. Vi vet i dag ikke nøyaktig hva i denne prosessen som leder til nedsatt nevronal funksjon, men i patogenesen inngår aktivering av immunsystemet med cytokiner som fører til inflammasjon (15). Ved familiær Alzheimers sykdom er det beskrevet flere mutasjoner i APPgenet som fører til en betydelig økt produksjon av de lange og mere aggregeringstilbøyelige formene for amyloid- $\beta$-peptider (16). Det samme finner man ved trisomi av kromosom 21 , som er den vanligste årsaken til Downs syndrom. Det er kjent at personer

\section{ApoE}

ApoE-genet finnes som tre ulike alleler, $\varepsilon 2$, $\varepsilon 3$ og $\varepsilon 4$, og koder for apolipoprotein $\mathrm{E}$ (26). \&4-allelet ble i 1993 knyttet til risiko for utvikling av den vanlig forekommende og sent debuterende formen av Alzheimers sykdom (27). Proteinet med samme navn er viktig for transport av lipoproteiner som inneholder kolesterol, og det er derfor blitt studert som en kardiovaskulær risikofaktor. $A p o E$ er også undersøkt for sin rolle som immunmodulator og risikofaktor for Alzheiaffektive og apatiske tilleggssymptomer (28). Apolipoprotein E forsterker enzymatisk nedbrytning av $\beta$-amyloid. $\varepsilon 4$-kodede varianter av proteinet er mindre effektive $i$ denne oppgaven (28). Ulike kombinasjoner av allelene gir ulik risiko for å utvikle Alzheimers sykdom og innvirker på når sykdommen starter. Hollingworth og medarbeidere har beregnet at $A p o E$ er ansvarlig for mers sykdom, der $\varepsilon 4$-status er assosiert med 
13,6\% av forekomsten av Alzheimers sykdom i befolkningen (29) (fig 1). Dersom man har ett $\varepsilon 4$-allel, har man 2-3 ganger høyere sannsynlighet for å få sykdommen før 96 års alder sammenliknet med gjennomsnittsbefolkningen. Ved to alleler, $\varepsilon 4 \varepsilon 4$, er risikoen økt med 10-20 ganger (26). Risikokurver basert på alder, kjønn, familiær belastning av Alzheimers sykdom og antall $\varepsilon 4$-alleler er publisert (30). En nyere større studie viser at livstidsrisikoen for å utvikle Alzheimers sykdom er $51 \%$ for menn med to ApoE \&4-alleler og $60 \%$ for kvinner med to slike alleler (31).

Det er imidlertid viktig å være klar over at ett eller to $\varepsilon 4$-alleler verken er tilstrekkelig eller nødvendig for å utvikle Alzheimers sykdom. Om lag en tredel av personer med Alzheimers sykdom har ingen $\varepsilon 4$-alleler (26). Foreliggende retningslinjer (3) anbefaler derfor ikke at $A p o E$ testes i klinisk sammenheng ved utredning av kognitiv svikt og demens. Etter forfatternes kjennskap gjøres dette heller ikke i Norge i dag.

\section{Nye risikogener}

Ny teknologi har muliggjort helgenomassosiasjonsstudier (Genome Wide Association Studies, GWAS). Denne metoden har i løpet av de siste årene ført til at man har identifisert mange nye risikogener som er assosiert med Alzheimers sykdom (29) (ramme 1). 695 gener er nå ifølge Alzgene-databasen forbundet med utvikling av Alzheimers sykdom $(4,26) .11$ av disse er replisert i flere studier av ulike populasjoner der det er personer med Alzheimers sykdom. Dette gjelder i tillegg til $A p o E \& 4$ ti gener: $C L U$, PICALM, CR1, BIN1, MS4A, CD2AP, CD33, ABCA7, EPHA og TREM2 (32-36).

Genet $C L U$ koder for proteinet clusterin, også kalt apolipoprotein J. Det har funksjonelle likheter med apolipoprotein $\mathrm{E}$ og er et protein som binder til $\beta$-amyloid i hjernen. Høy konsentrasjon av clusterin målt $\mathrm{i}$ plasma ble nylig funnet å være assosiert med atrofi av entorhinal cortex og rask progresjon av Alzheimers sykdom (37). En mulig forklaring på dette kan være at risikovariantene av $C L U$ ved Alzheimers sykdom gir økt genekspresjon og dermed større proteinproduksjon. $C L U$ knyttes både til amyloidhypotesen, kolesterolmetabolisme og immunsystemet (29).

Genet PICALM koder for fosfatidyl-inositol-bindende klatrinsamlende protein som er involvert $\mathrm{i}$ transport av vesikkelassosiert membranprotein 2 (VAMP2). Dette er en prosess i nevrotransmitterfrigjøringen i den synaptiske spalten og involverer danning av synaptiske vesikler. Dette genet knyttes derfor til synaptisk dysfunksjon ved Alzheimers sykdom (29).

BIN1 (brodannende integrator 1) koder for proteinet med samme navn, også kalt amfifysin 2 . Dette proteinet er på samme måte som PICALM involvert i klatrinmediert endocytose og kan påvirke risikoen for Alzheimers sykdom ved å virke inn på nevronale membraner samt transport og danning av synapser, dermed også kommunikasjonen mellom hjerneceller (29).

Genet CRl koder for komplementkomponent reseptor 1, også kalt C3b. Dette binder amyloid- $\beta$-peptider og kan hjelpe uttransport av $A \beta-42$ fra hjernen. Funnet er med på å underbygge sammenhengen mellom Alzheimers sykdom og både amyloidhypotesen og inflammasjonssystemet (29).

$M S 4 A, \quad C D 2 A P, \quad C D 33, \quad A B C A 7$ og $E P H A 1$ ble nylig påvist som risikogener for Alzheimers sykdom i to helgenomassosiasjonsstudier fra to uavhengige utvalg, ett fra USA (34) og et annet fra Europa (32). MS4A tilhører en familie av gener som koder for en gruppe av membranproteiner som blant annet opptrer som membranproteiner på B-celler og derfor kobles til immunsystemet (32). Genet CD2AP knyttes til synaptisk dysfunksjon og ulike cellemembranprosesser (32). CD33 (sialic acid-binding Ig-like lectin 3, siglec-3) knyttes både til immunsystemet og til synaptisk dysfunksjon (32). $A B C A 7$ (ATP-binding cassette transporter) knyttes til både immunsystemet og til kolesterolmetabolismen (32). EPHA1 (efrinreseptor A1) koder for efrinreseptor 1 som er en del av efrinreseptorfamilien. Disse proteinene spiller en rolle ved celle- og aksonmigrasjon

\section{RAMME 1}

\section{Helgenomassosiasjonsstudie (GWAS)}

Helgenomassosiasjonsstudier (GWAS) er en ny metode som gjør det mulig å undersøke over $80 \%$ av variasjonen i det menneskelige genom på begrenset tid uten store kostnader (29). Metoden er egnet til å påvise vanlige genetiske varianter som er assosiert med sykdom. Man undersøker et høyt antall syke og sammenlikner enkeltnukleotidpolymorfismer (single nucleotide polymorphism, SNP) i genomet med enkeltnukleotidpolymorfismene hos friske kontrollpersoner. Flere nye gener som er assosiert med utvikling av Alzheimers sykdom og andre sykdommer med kompleks arv er oppdaget ved bruk av denne metoden.

samt for danning og plastisitet av synapser. Proteinene har i tillegg funksjoner ved apoptose og inflammasjon og knyttes derfor ved Alzheimers sykdom både til immunsystemet og til synaptisk dysfunksjon (32). TREM2 koder for et protein som i hjernen er uttrykt på mikrogliaceller og fjerner degenerert vev og vevsbiter, inkludert rester fra nevroinflammasjon (38).

Disse ti genene pluss $A p o E$ forklarer nå om lag halvparten av genetikken ved sent debuterende og sporadisk opptredende Alzheimers

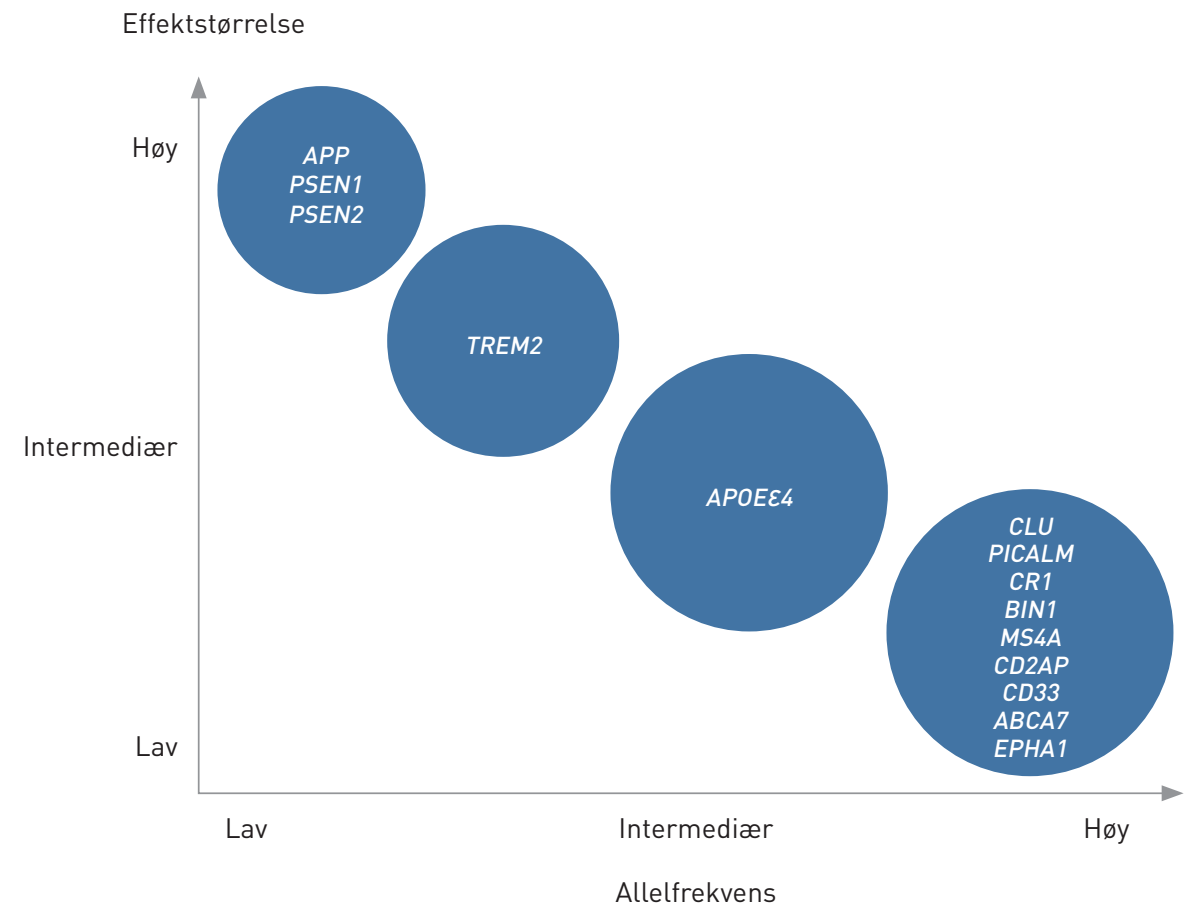

Figur 2 Relativ allellfrekvens $i$ befolkningen og effektstørrelse av nye risikogener og mutasjoner $i$ APP, PSEN1 og PSEN2 ved Alzheimers sykdom (19-21, 27, 32, 34, 35) 
sykdom (36) (fig 1). Dermed er denne tilstanden en av de best kartlagte sykdommene med hensyn til kompleks arv (39). Større helgenomassosiasjonsstudier vil kunne avdekke flere gener som er assosiert med sykdommen, men denne metoden er ikke utviklet for å avdekke sjeldne mutasjoner. Andre genetiske forhold som ikke kan avdekkes av slike studier og som kan ha betydning ved Alzheimers sykdom er gen-gen-interaksjoner, flere kopier av samme gen som duplikasjon og triplikasjon, epigenetisk variasjon og RNA-prosessering (39). Risikogenene definerer nye primære sykdomsmekanismer ved Alzheimers sykdom, mekanismer som dels er uavhengige av den inntil nå dominerende amyloidhypotesen. De nye hypotesene baseres på aktivering av immunsystemet med nevroinflammasjon, endret kolesterolmetabolisme i hjernen og synaptiske cellemembranprosesser. Alle nye identifiserte risikogener kan knyttes til én eller flere av disse mekanismene (39), som åpner nye muligheter for utvikling av sykdomsmarkører og potensielt sykdomsmodifiserende behandling mot Alzheimers sykdom.

Selv om vi nå kjenner til ti nye risikogener for utvikling av vanlig Alzheimers sykdom, har hvert enkelt gen liten og ulik effekt på risikoen hos den enkelte pasient (fig 2). Per i dag kan man ved genetisk veiledning ikke benytte funn av disse genene til risikovurdering for fremtidig demensutvikling hos personer med Alzheimers sykdom i nær familie (29). Klinisk er genetisk veiledning og testing i dag først og fremst aktuelt $i$ familier med dominant arvegang, der tre eller flere er rammet $i$ to eller flere generasjoner og der to av disse er førstegradsslektninger. En detaljert veileder for klinikere om hvilke pasienter som er aktuelle for genetisk veiledning og testing er nylig publisert (3).

\section{Arvid Rongve (f. 1969)}

er spesialist i psykiatri med fordypningsområde i alderspsykiatri og er seksjonsoverlege og postdoktorforsker. Forskningsområder er demens og genetikk, særlig demens med lewylegemer. Forfatter har fylt ut ICMJE-skjemaet og oppgir ingen interessekonflikter.

\section{Dag Årsland (f. 1959)}

er spesialist i psykiatri, med spesialkompetanse i alderspsykiatri og nevropsykiatri. Han er forskningssjef ved Senter for eldremedisin og samhandling, professor i klinisk demensforskning ved Alzheimer Centrum og seniorforsker ved Alderspsykiatrisk avdeling.

Forfatter har fylt ut ICMJE-skjemaet og oppgir følgende interessekonflikter: Han har fått konsultasjonshonorar fra Lundbeck, foredragshonorar fra Lundbeck og Novartis og midler til utarbeiding av manuskript fra Lundbeck. Institusjonen har fått tilskudd fra GE Health.

\section{Caroline Graff (f. 1965)}

er spesialist i klinisk genetikk med fordypningsområde i nevrodegenerative sykdommer. Hun er professor i genetisk demensforskning. overlege med ansvar for en klinisk-genetisk hukommelsespoliklinikk som utreder arvelige demenssykdommer, og leder for Hjernebanken ved Karolinska Institutet.

Forfatter har fylt ut ICMJE-skjemaet og oppgir følgende interessekonflikter: Hun har mottatt styrehonorar fra Governmental Ethical Review Board. Studiene er delfinansiert av Karolinska Institutet (KID-funding og forskerstipend), Swedish Brain Power, Stockholms läns landsting. Vetenskapsrådet, Marianne och Marcus Wallenbergs Stiftelse, Stohnes foundation, Alzheimer Fonden, Roche, Konung Gustaf V: s och Drottning Victorias Frimurarestiftelse. Hun har også mottatt forelesningshonorar fra Lundbeck.

\section{Litteratur}

. Hjort PF, Waaler HT. Demens frem mot 2050. Tidsskr Nor Legeforen 2010; 130: 1356-8.

2. Aarsland D, Rongve A, Nore SP et al. Frequency and case identification of dementia with Lewy bodies using the revised consensus criteria. Dement Geriatr Cogn Disord 2008; 26: 445-52.

3. Goldman JS, Hahn SE, Catania JW et al. Genetic counseling and testing for Alzheimer disease: joint practice guidelines of the American College of Medical Genetics and the National Society of Genetic Counselors. Genet Med 2011; 13: 597-605.

4. Bertram L, McQueen MB, Mullin K et al. Systematic meta-analyses of Alzheimer disease genetic association studies: the AlzGene database. Nat Genet 2007; 39: 17-23

5. Engedal K, Haugen PK, Brækhus A. Demens fakta og utfordringer: en lærebok. 5 utg. Oslo: Aldring \& Helse, 2009

6. Ritchie K, Carrière I, Ritchie CW et al. Designing prevention programmes to reduce incidence of dementia: prospective cohort study of modifiable risk factors. BMJ 2010: 341: c3885.

7. Barnes DE, Yaffe K. The projected effect of risk factor reduction on Alzheimer's disease prevalence. Lancet Neurol 2011; 10: 819-28.

8. Bergem AL, Engedal $K$, Kringlen $\mathrm{E}$. The role of heredity in late-onset Alzheimer disease and vascular dementia. A twin study. Arch Gen Psychiatry 1997; 54: 264-70

9. Gatz M, Pedersen NL, Berg S et al. Heritability for Alzheimer's disease: the study of dementia in Swedish twins. J Gerontol A Biol Sci Med Sci 1997 52: M117-25.

10. Kiejna A, Frydecka D, Adamowski T et al. Epidemiological studies of cognitive impairment and dementia across Eastern and Middle European countries lepidemiology of dementia in Eastern and Middle European Countries). Int J Geriatr Psychiatry 2011; 26: $111-7$

11. Graff AC. Ärftlighet vid Alzheimer's sjukdom. Nordisk geriatrik 2005; 1: 4-6

12. van Duijn CM, Clayton D, Chandra V et al. Familial aggregation of Alzheimer's disease and related disorders: a collaborative re-analysis of case-control studies. Int J Epidemiol 1991. 20 (suppl 2). S13-20.

13. Zhou ZD, Chan CH, Ma QH et al. The roles of amyloid precursor protein (APP) in neurogenesis: Implications to pathogenesis and therapy of Alzheimer disease. Cell Adhes Migr 2011; 5: 280-92.

14. Finder VH, Glockshuber R. Amyloid-beta aggregation. Neurodegener Dis 2007; 4: 13-27.

15. Zotova E, Nicoll JA, Kalaria R et al. Inflammation in Alzheimer's disease: relevance to pathogenesis and therapy. Alzheimers Res Ther 2010; 2:

16. Galimberti D, Scarpini E. Genetics and biology of Alzheimer's disease and frontotemporal lobar degeneration. Int J Clin Exp Med 2010; 3: 129-43.
17. Zigman WB, Lott IT. Alzheimer's disease in Down syndrome: neurobiology and risk. Ment Retard Dev Disabil Res Rev 2007; 13: 237-46.

18. Avramopoulos D. Genetics of Alzheimer's disease recent advances. Genome Med 2009; 1: 34.

19. Goate A, Chartier-Harlin MC, Mullan M et al. Segregation of a missense mutation in the amyloid precursor protein gene with familial Alzheimer's disease. Nature 1991; 349: 704-6.

20. Sherrington R, Rogaev El, Liang Y et al. Cloning of a gene bearing missense mutations in early-onset familial Alzheimer's disease. Nature 1995; 375: 754-60.

21. Levy-Lahad E, Wasco W, Poorkaj P et al. Candidate gene for the chromosome 1 familial Alzheimer's disease locus. Science 1995; 269: 973-7.

22. Jonsson T, Atwal JK, Steinberg $\mathrm{S}$ et al. A mutation in APP protects against Alzheimer's disease and agerelated cognitive decline. Nature 2012; 488: 96-9

23. Mangialasche F, Solomon A, Winblad B et al. Alzheimer's disease: clinical trials and drug development. Lancet Neurol 2010; 9: 702-16.

24. Russell MB. Genetics of dementia. Acta Neurol Scand Suppl 2010; 122: 58-61.

25. Bekris LM, Yu CE, Bird TD et al. Genetics of Alzheimer disease. J Geriatr Psychiatry Neurol 2010; 23: 213-27.

26. Olgiati P, Politis AM, Papadimitriou GN et al. Genetics of late-onset Alzheimer's disease: update from the alzgene database and analysis of shared pathways. Int J Alzheimers Dis 2011; 2011: 832379.

27. Corder EH, Saunders AM, Strittmatter WJ et al. Gene dose of apolipoprotein E type 4 allele and the risk of Alzheimer's disease in late onset families. Science 1993: 261:921-3.

28. D'Onofrio G, Panza F, Seripa D et al. The APOE polymorphism in Alzheimer's disease patients with neuropsychiatric symptoms and syndromes. Int J Geriatr Psychiatry 2011; 26: 1062-70.

29. Hollingworth $P$. Harold D, Jones L et al. Alzheimer's disease genetics: current knowledge and future challenges. Int J Geriatr Psychiatry 2011 26: 793-802

30. Roberts JS, Cupples LA, Relkin NR et al. Genetic risk assessment for adult children of people with Alzheimer's disease: the Risk Evaluation and Education for Alzheimer's Disease (REVEAL) study. J Geriatr Psychiatry Neurol 2005; 18: 250-5.

31. Genin E, Hannequin D. Wallon D et al. APOE and Alzheimer disease: a major gene with semi-dominant inheritance. Mol Psychiatry 2011; 16: 903-7.

32. Hollingworth $P$, Harold D, Sims R et al. Common variants at ABCA7, MS4A6A/MS4A4E, EPHA1. CD33 and CD2AP are associated with Alzheimer's disease. Nat Genet 2011; 43: 429-35.

33. Harold D, Abraham R, Hollingworth $P$ et al. Genome-wide association study identifies variants at CLU and PICALM associated with Alzheimer's disease. Nat Genet 2009; 41: 1088-93.

34. Naj AC, Jun G, Beecham GW et al. Common variants at MS4A4/MS4A6E, CD2AP, CD33 and EPHA are associated with late-onset Alzheimer's disease. Nat Genet 2011: 43: 436-41.

35. Jonsson T, Stefansson H, Steinberg $\mathrm{S}$ et al. Variant of TREM2 associated with the risk of Alzheimer's disease. N Engl J Med 2013; 368: 107-16.

36. Guerreiro R, Wojtas A, Bras J et al. TREM2 variants in Alzheimer's disease. N Engl J Med 2013; 368: 117-27

37. Thambisetty $M$, Simmons $A$, Velayudhan $L$ et al. Association of plasma clusterin concentration with severity, pathology, and progression in Alzheimer disease. Arch Gen Psychiatry 2010; 67: 739-48.

38. Neumann H, Daly MJ. Variant TREM2 as risk factor for Alzheimer's disease. N Engl J Med 2013; 368: $182-4$

39. Morgan K. The three new pathways leading to Alzheimer's disease. Neuropathol Appl Neurobiol 2011; 37: 353-7.

Mottatt 6.8. 2012, første revisjon innsendt 3.1 2013, godkjent 26.4. 2013. Medisinsk redaktør Are Brean. 